\title{
Strategi Kepemimpinan Kepala Madrasah dalam Mewujudkan Mutu di Insan Cendekia Halmahera Barat Maluku Utara
}

\author{
Buyung Ismu Tawary ${ }^{1}$ \\ ${ }^{1}$ Universitas Islam Negeri Sunan Kalijaga Yogyakarta \\ email: buyungtawary@gmail.com
}

\begin{abstract}
This research is based on the establishment of MAN Insan Cendekia in 2017, with all the achievements that Madrasahs have as a measure of quality. The purpose of this research is to find out how the leadership strategy of Insan Cendekia Halmahera Barat madrasah in realizing the quality of madrasah. This research is a descriptive qualitative research, with a phenomenological approach that occurs in the field. Collecting data using observation, in-depth interviews and documentation. The data analysis technique used three lines of analysis, namely data reduction, data presentation and ferification. The results of this study indicate that: The strategy of implementing and evaluating the quality of education in the West Halmahera Intellectuals is carried out in three ways: first: provision of adequate facilities and infrastructure, second: increasing teacher competence and third: developing student potential in the field of science and technology and IMTAQ as a program flagship madrasa. The full support of the central government and local governments for the development of madrasah is a supporting factor in realizing quality. The results obtained from improving the quality of education are the increase in the construction of madrasa facilities, and student achievements obtained from competitions in the field of Science and technology and and MAN Insan Cendekia West Halmahera accredited $A$ in 2018 with a total score of 92.
\end{abstract}

Keywords: leadership strategy, quality madrasah

\begin{abstract}
ABSTRAK
Penelitian ini dilatar belakangi atas berdirinya MAN Insan Cendekia pada tahun 2017, dengan kepemimpinan kepala madrasah yang pertma, Tujuan dari penelitian ini untuk mengetahui bagaimana strategi kepemimpinan kepala madrasah Insan Cendekia Halmahera Barat dalam mewujudkan mutu madrasah. Penelitian ini merupakan penelitian kualitatif deskriptif, dengan pendekatan fenomenologi yang terjadi di lapangan. Pengumpulan data menggunakan observasi, wawancara mendalam dan dokumentasi. Teknik analisis data menggunakan tiga alur analisis yaitu reduksi data, penyajian data dan ferifikasi. Hasil dari penelitian ini menunjukan bahwa: Strategi pelaksanaan dan evaluasi mutu pendidikan di Insan Cendekia Halmahera Barat dilaksanakan dalam tiga cara yang pertama: penyediaan sarana dan prasarana yang memadai, kedua: peningkatan kompetensi guru dan ketiga: mengembangkan potensi siswa di bidang IPTEK dan IMTAQ sebagai program unggulan madrasah. Dukungan penuh pemerintah pusat dan pemerintah daerah untuk pengembangan madrasah merupakan faktor pendukung dalam mewujudkan mutu. Hasil yang didapat dari peningkatan mutu pendidikan adalah, meningkatnya pembangunan fasilitas madrasah, dan prestasi siswa yang diperoleh dari perlombaan di bidang Sains dan teknologi serta, MAN Insan Cendekia Halmahera barat terakreditasi A pada tahun 2018 dengan jumlah nilai 92.
\end{abstract}

Kata kunci: strategi kepemimpina, madrasah bermutu 


\section{PENDAHULUAN}

Strategi merupakan kunci sukses dalam mencapai tujuan madrasah. Kepala madrasah yang baik adalah kepala madrasah yang memiliki strategi jitu dalam memajukan madrasah. Tanpa ada strategi maka program madrasah tidak akan berjalan. Starategi adalah langkah awal dan terpenting ketika pemimpin berniat memajukan madrasah. Sehebat apapun seorang pimpinan jika ia tidak memiliki strategi yang baik dan jitu maka programnya akan tak berarti. Kepemimpinan tidak hanya mengadalkan kemampuan sang pemimpin namun juga strategi sang pemimpin. Menurut David, Strategis dapat didefinisikan sebagai seni dan pengetahuan dalam merumuskan, mengimplementasikan, serta mengevaluasi keputusankeputusan lintas-fungsional yang memampukan sebuah organisasi mencapai tujuannya (Fred David, 2009: 5).

Masyarakat sebagai konsumen pendidikan, sudah mulai mempertanyakan dan memilih sekolah-sekolah berkualitas, karena mereka khawatir putra-putrinya tidak mampu dan bahkan kalah bersaing di era globalisasi saat ini. Kenyataan di atas menunjukkan bahwa, globalisasi sesungguhnya meniscayakan budaya kompetitif sebagai instrumen penting dalam proses perkembangannya, termasuk dalam bidang pendidikan. Di beberapa daerah di Indonesia misalnya banyak orang tua yang berkeinginan untuk menyekolahkan anak-anak mereka di lembaga pendidikan yang berkualitas tinggi, jika kualitas menjadi sasaran utama dari konsumen pendidikan dewasa ini. Maka madrasah yang tergolong rendah kualitas pendidikan akan tertinggal jauh dari madrasah yang berkualitas tinggi.

Untuk mencapai Generasi Emas pada tahun 2045, bangsa Indonesia perlu dipersiapkan segala kebutuhan semenjak dini, agar kelak, anak-anak didik mencapai nobel diberbagai bidang kehidupan seperti nobel fisika, biologi, kesehatan, sastra sampai nobel perdamaian. Sehinggga dapat bersaing dikanca Internasional, lembaga pendidikan harus banyak membangun jejaring, kepercayaan dan norma yang menjadi pijakan hubungan timbal balik. Kesemuannya ini melekat dan ada madrasah baik secara internal maupun eksternal. Kemampuan sekolah mengenali dan memanfaatkan serta mengembangkan modal sosial menjadi kunci keberhasilan kepemimpinan madrasah (Suwadi, 2015).

Pola yang dimainkan oleh lembaga pendidikan untuk merai mutu pastilah berbeda-beda. Ada lembaga yang tampil dengan memperkuat jaringan, ada yang mengedepankan fasilitas, ada yang memperkokoh sumber daya manusianya (SDM) dan lain sebagainya. Kunandar berpandangan bahwa, pendidikan merupakan kunci modernisasi atau pendidikan adalah investasi manusia untuk memperoleh pengakuan dari banyak kalangan. Pengembangan dan 
pembangunan SDM adalah salah satu yang menjadi syarat dalam pembangunan suatu bangsa (Kunandar, 2007: 10).

Peneliti melihat perkembangan MAN Insan Cendekia tiga tahun terakhir, memiliki kemajuan yang sangat signifikin, di mulai pada peningkatan pembelajaran siswa, pembangunan organisasi lembaga, peningkatan sarana dan prasarana. Apabila di liat perkembangan madrasah kususnya di Provinsi Maluku Utara, masih sangat jauh di bandingkan perkembangan madrasah-madrasah di kota-kota maju lainnya, padahal sudah sangat banyak madrasah di kota-kota besar yang dapat di jadikan model dalam pengembangan madrasah, tinggal bagaimana keseriusan pihak madrasah dan didukung oleh pemerintah setempat sehingga mampu mengembangkan seperti halnya madrasah di kotakota besar lainnya, dan tidak menjadi seperti perkataan Prof. Mujamil Qomar dalam bukunya menyebutkan madrasah di Indonesia seperti sudah memiliki dalil tunggal yaitu " $l a$ yahya wala yamutu"(hidup enggan mati tak mau) (Mujamil Qomar, 2007: 3).

MAN Insan Cendekia secara sadar dibangun karena dorongan kebutuhan ideal, yaitu menghasilkan lulusan pendidikan tingkat menengah berbasis ke-Islaman yang kuat di bidang iman dan takwa (IMTAK), akhlak mulia, ilmu pengetahuan dan teknologi (IPTEK), dan seni budaya, untuk menjawab tantangan yang dihadapi masyarakat dewasa ini. Upaya menuju keseimbangan yang unggul, perpaduan antara kecerdasan intelektual, emosional, spiritual, dan social adalah cita-cita yang hendak dicapai dari program pendidikan MAN Insan Cendekia, dengan model berasrama (boarding school) dengan predikat aktreditas A dalam kurung waktu dua tahun berjalan, telah menunjukkan sejumlah keberhasilan yang menakjubkan sehingga dapat bersaing dengan sekolah/madrasah di Provinsi Maluku Utara (http://www.manichalbar.sch.id/profil.php?id=profil\&kode=12\&profil=Sejarah\%20Singka t).

\section{Indikator Manajemen Mutu Pendidikan.}

Untuk mengukur pendidikan yang berkualitas tentunya diperlukan kriteria/ indikator. Sallis (2005: 1-2) mengungkapkan ada banyak indikator mutu yang baik di lembaga pendidikan. Antara lain: 1) nilai-nilai moral/ karakter yang tinggi; 2) hasil ujian yang sangat baik; 3) dukungan orang tua, dunia usaha dan masyarakat setempat; 4) sumber daya berlimpah; 5) implementasi teknologi terbaru; 6) kepemimpinan yang kuat dan memiliki tujuan (visi); 7) keperdulian dan perhatian bagi siswa; 8) kurikulum yang seimbang dan relevan (Muhammad Fadhli, 2017). 
Hoy, Jardine and Wood (2005: 11-12) quality in education is an evaluation of the process of educating which enhances the need to achieve and develop the talents of the customers of the process, and at the same time meets the accountability standards set by the clients who pay for the process or the outputs from the process of educating. Pendapat ini menjelaskan bahwa mutu dalam pendidikan adalah evaluasi proses pendidikan yang meningkatkan kebutuhan untuk mencapai dan proses mengembangkan bakat para pelanggan (peserta didik), dan pada saat yang sama memenuhi standar akuntabilitas yang ditetapkan oleh klien (stakeholder) yang membayar untuk proses atau output dari proses pendidikan (Muhammad Fadhli, 2017).

Untuk meningkatkan mutu pendidikan perlu dilihat dari banyak sisi. Telah banyak pakar pendidikan mengemukakan pendapatnya tentang faktor penyebab dan solusi mengatasi kemerosotan mutu pendidikan di lndonesia. Mutu adalah hal yang esensial sebagai bagian dalam proses pendidikan. Proses pembelajaran adalah tujuan organisasi pendidikan. Mutu pendidikan adalah mutu lulusan dan pelayanan yang memuaskan pihak terkait pendidikan. Mutu lulusan berkaitan dengan lulusan dengan nilai yang baik (kognitid, apektif, dan psikomotorik) diterima melanjutkan ke jenjang yang lebih tinggi yang berkualitas dan memiliki kepribadian yang baik.

\section{Faktor Pengendalian Mutu Pendidikan}

Mutu biasanya sebagaimana yang di ungkapkan Finda Nestria Jelita dan Ary Ferdia (2019: 46) dikendalikan melalui PDCA (Plan, Do, Check, Act) pada proses penyelenggaraan pendidikan sekolah/madrasah, dibawah ini merupakan penjabaran dari sirklus PDCA:

1) Plan atau perencanaan, perencanaan mutu yang dilakukan di sekolah, dimana kepala sekolah menetapkan kebijakan mutu dan tujuan mutu dengan indikator pencapaiannya. Kemudian diikuti dengan penetapan prosedur mutu (SOP) untuk pencapaian tujuan mutu.

2) Do atau pelaksanaan, pelanksanaan standar sekolah atau madrasah. Untuk memastikan dan menjamin mutu pendidikan dalam sekolah maka seluruh proses kegiatan belajar mengajar, pelayanan administrasi dilaksanakan dan didasarkan sesuai dengan dokumen mutu yang telah ditetapkan. Kepala sekolah dibantu dengan tim penjamin mutu bertanggung jawab dalam mengendalikan seluruh proses kegiatan, berdasarkan pada dokumen mutu. Pemberdayaan tenaga pendidik dan tenaga kependidikan serta pencapaian kompetensi agar dapat menjalankan peran dan tugas masing-masing. 
3) Check atau evaluasi. Pelaksanaan proses pendidikan dan penjaminan mutu dapat dilakukan dengan tiga cara, yaitu evaluasi diri oleh sekolah, audit internal terhadap proses pendidikan dan hasilnya oleh auditor internal, dan evaluasi oleh pihak eksternal yaitu oleh Badan Akreditasi atau Sertifikasi.

4) Act atau tindak lanjut. Hasil dari proses evaluasi (monitoring, evaluasi diri, dan audit internal) dibahas dan dikomunikasikan oleh kepala sekolah dengan pihak-pihak yang berkepentingan. Pihak berkepentingan yang dimaksud ialah seperti komite sekolah, guru, karyawan, orang tua siswa, dan lainnya. Hal ini bertujuan untuk mendapat umpan balik, melakukan tindak lanjut dari hasil evaluasi dan perbaikan.

Faktor penting dalam strategi kepemimpinan kepala madrasah untuk mewujudkan mutu, kepala madrasah mempunyai tanggung jawab untuk mengajar dan mempengaruhi semua pihak yang terlibat dalam kegiatan pendidikan di madrasah untuk bekerja sama dalam mencapai tujuan madrasah. Dalam manajemen modern seorang pemimpin juga harus berperan sebagai pengelola. Dilihat dari fungsi-fungsi manajemen, yakni planning (Perencanaan), organizing (pengorganisasian) dan controling 5 (pengawasan), maka kepala madrasah harus berperan pula sebagai supervisor pengajaran serta sebagai evaluator program sekolah (Muh Hadi, 2014).

Dalam menerapkan suatu strategi kepala madrasah harus menganalisis yang tepat tentang kekuatan yang dimiliki oleh madrasah serta kelemahan yang mungkin melekat pada madrasah, berbagai peluang yang mungkin timbul dan harus dimanfatkan serta ancaman yang diperkirakan akan dihadapi. Dalam hal ini MAN Insan Cendekia Halmahera Barat memilki peluang dalam penerapan strategi sebagai madrasah yang baru berdiri, seperti sarana dan presarana, guru-guru yang memiliki kompetensi, prestasi-prestasi siswa dan program unggulan sebagai madrasah berasrama (boarding school). Dari semua itu selanjutnya kepala madrasah harus memperhatikan pentingnya operasionalisasi keseluruhan kebijakan dasar yang dibuat dengan memperhitungan kemampuan madrasah di bagian tersebut. Sehingga dapat menciptakan umpan balik sebagai instrument ampuh bagi semua pihak yang terlibat dalam pelaksanaan strategi yang telah ditentukan itu untuk mengetahui apakah sasaran terlampaui atau hanya sekedar tercapai atau mungkin bahkan tidak tercapai. Kesemuanya itu diperlukan sebagai bahan dan dasar untuk mengambil keputusan di masa depan. 


\section{Sarana dan Prasarana Madrasah Insan Cendekia Halbar}

Sarana prasana merupakan indikator dalam pelaksanaan mutu, ada dua istilah yang menunjukan pemahaman sarana dan prasarana pendidikan. Pertama, istilah fasilitas adalah prasarana yang mempermudah pelaksanaan kegiatan. Fasilitas bisa pula di anggap sebagai suatu alat. Fasilitas biasanya di hubungkan kebutuhan umum dalam suatu lembaga atau organisasi . Fasilitas pendidikan merupakan salah satu fasilitas social yang penting bagi penduduk. Fasilitas pada lembaga pendidikan sama seperti fasilitas sosial pada lembagalembaga lainnya, fasilitas perkantoran, fasilitas ibadah, fasilitas umum, yang menjadi perhatian pemerintah untuk memenuhi (H.A. Rusdiana, 2015).

Tabel 1.

Fasilitas Man Insan Cendekia Halbar

Luas Tanah Man Insan Cendekia Halmahera Barat Adalah 13,5 Hektar. (Sertifikat).

Kondisi sarana dan prasarana MAN Insan Cendekia Halmahera Barat.

\begin{tabular}{|c|c|c|c|c|c|}
\hline No & Nama Sarana & Jml & $\begin{array}{c}\text { Ukuran/ } \\
\text { Jenis }\end{array}$ & Keterangan & $\begin{array}{c}\text { Sumber dana } \\
\text { \& Tahun } \\
\end{array}$ \\
\hline 1 & Ruang Kelas Belajar & 16 & $\begin{array}{l}8 \mathrm{~m} \times 7 \mathrm{~m} \\
\text { Permanen }\end{array}$ & B & APBN 2013 \\
\hline 2 & Asrama Putra & 15 & $\begin{array}{l}7 \mathrm{~m} \times 7 \mathrm{~m} \\
\text { Permanen }\end{array}$ & B & APBN 2014 \\
\hline 3 & Asrama Putri & 15 & $\begin{array}{l}7 \mathrm{~m} \times 7 \mathrm{~m} \\
\text { Permanen }\end{array}$ & $\mathrm{P}$ & APBN 2014 \\
\hline 4 & $\begin{array}{c}\text { Kantin/Dapur/Ruang } \\
\text { Makan }\end{array}$ & 1 & $\begin{array}{c}40 \mathrm{~m} \times 30 \\
\mathrm{~m} \\
\text { Permanen }\end{array}$ & R. R & APBN2014 \\
\hline 5 & Masjid & 1 & $\begin{array}{c}30 \mathrm{~m} \times 30 \\
\mathrm{~m} \\
\text { Permanen }\end{array}$ & R.R & APBN 2018 \\
\hline 6 & Gapura /Gerbang & 1 & & R.R & APBN 2018 \\
\hline 7 & $\begin{array}{c}\text { Kantor dan Ruang } \\
\text { Guru } \\
3 \text { lantai }\end{array}$ & 1 & & $\mathrm{P}$ & $\begin{array}{c}\text { APBN } \\
2016,2017,2018\end{array}$ \\
\hline 8 & Rumah dinas guru & 10 & $\begin{array}{c}8 \mathrm{~m} \times 5 \mathrm{~m} \\
\text { Permanen }\end{array}$ & B & APBN 2018 \\
\hline 9 & Wc/Kamar mandi & 50 & $\begin{array}{l}2 \mathrm{~m} \times 2 \mathrm{~m} \\
\text { Permanen }\end{array}$ & R.R & APBN 2014 \\
\hline 10 & Bak Air & 2 & $(6 \times 6 \times 6) \mathrm{m}$ & B & APBN 2015 \\
\hline 11 & Sumur Bor & 1 & & B & APBN 2015 \\
\hline 12 & Bel Kelas & 10 & Permanen & B & APBN 2018 \\
\hline 13 & Airphone/PABX & & & B & APBN 2018 \\
\hline 14 & Mobil Operasional & 1 & Bekas & R. R & $\begin{array}{l}\text { Bantuan Kanwil } \\
\text { Kemenag Malut }\end{array}$ \\
\hline
\end{tabular}




\begin{tabular}{|c|l|c|l|c|c|}
\hline 15 & $\begin{array}{l}\text { Gedung Aula Serba } \\
\text { guna }\end{array}$ & 1 & Permanen & B & APBN 2019 \\
\hline 16 & Alat Musik & $\begin{array}{c}1 \\
\text { set }\end{array}$ & & B & APBN 2018 \\
\hline 17 & Tenis Meja & 2 & & B & APBN 2018 \\
\hline 18 & Bulu Tangkis & 1 & Permanen & B & APBN 2019 \\
\hline
\end{tabular}

\begin{tabular}{ll}
\multicolumn{2}{l}{ Keterangan: } \\
$\mathrm{B}$ & :Baik \\
$\mathrm{P}$ & :Proses \\
$\mathrm{RR}$ & :Rusak Ringan \\
$\mathrm{RB}$ & :Rusak Berat
\end{tabular}

Sarana pendidikan adalah semua yang diperlukan dalam proses belajar mengajar baik yang bergerak maupun tidak bergerak agar pencapaian tujuan pendidikan dapat berjalan dengan lancar, teratur dan efesien. Jika dimanfaatkan secara langsung dengan baik manajemen sarana dan prasarananya dan terhadap pengelolaannya maka segala aspek pendidikan akan tumbuh dengan baik dan berkembang dengan baik pula, apalagi setiap aturan, prosedur dan kebijakan-kebijakan yang sudah ditetapkan dapat dilaksanakan dengan baik sehingga tujuan secara efektif dan efesien dapat terwujud sebagaimana yang diharapkan.

"untuk perencanaan anggaran pembangunan sarana madrasah Insan Cendekia Halmahera barat ini , pada Tahun anggaran 2020, ada beberapa bangunan yang sementara dalam proses pembangunan yaitu laboratorium, pembangunan kantor guru , asrama putri, perumahan dinas guru, bak penampungan air bersih, serta pembangunan jalan utama dan Penbangunan Gapura, ini sudah terferifikasi dan dalam tahapan pembangunan. rencananya akan berakhir di tahun 2020. Apabila ini sudah di selesaikan, tinggal menunggu pembangunan selanjutnya."

Dari penjelasan di atas, dan dibuktikan dengan tabel bahwa pembanguan gedung baru berupa laboratorium, asrama putri dan perumahan guru, dalam tahapan penyelesaian, untuk memberikan fasilitas yang memadai bagi terselenggaranya pendidikan yang bermutu, sangat di perlukan sarana sebagai alat penunjang pendidikan. Peneliti melihat bahwa, proses pembanguan sarana prasarana Man Insan Cendekia Halmahera Barat ini, berjalan sangat cepat, perhatian kusus oleh kementrian Agama ini menjadi nyata adanya. Tidak menutup kemungkinan MAN Insan Cendekia barat ini menjadi madrsah unggulan di wilaya Maluku Utara. Sudah saatnya pendidikan Agama di Maluku Utara ini mendapat perhatian lebih oleh kementrian pusat. Sebab ini menjadi tolak ukur untuk membina generasi muda Maluku Utara yang memiki kualitas unggulan. Tinggal bagaimana pemerintah daerah dan stekholder madrasah yang mewujudkan impian tersebut. 
"Mengenai fasilitas dan kesejahteran guru, di MAN Insan Cendekia ini sudah menyediakan perumahan untuk guru denga fasilitas lengkap, di tambah guru-guru diberikan bantuan berupa komputer, jaringan kusus guru, fasilitas ATK, dan lainlain, sehingga sangat terjangkau sekali di bandingkan dengan yang lain. Jadi menurut saya sangat merugi sekali kalau semua fasilitas ini tidak dipergunakan dengan baik, untuk meningkatkan kualitas madrasah."

Dari hasil wawancara diatas menunjukan bahwa, MAN Insan Cendekia menyediakan fasilitas memadai untuk kesejahteraan guru, ini sangat membantu untuk meningkatkan kinerja guru-guru MAN Insan Cendekia Halbar. Apalagi guru-guru di MAN Insan Cendekia ini sebagian besar adalah guru-guru Honorer. Fasilitas dan kesejahteraan guru tentunya merupakan sebuah keinginan setiap guru dalam menjalani profesinya sebagai guru. selain untuk memenuhi kebutuhan juga tentunya adalah untuk memiliki kesejahteraan yang layak. Sehingga bisa meningkatkan taraf kehidupan menuju kehidupan yang lebih baik dan juga layak, memotivasi diri sendiri untuk lebih semangat dalam menjalankan pekerjaannya, untuk menanamkan rasa kesadaran dan tanggug jawab dalam menjalankan tugas pekerjaannya dengan sebaik-baiknya. Karena peneliti mengamati problematikan pendidikan di Maluku Utara ini adalah kurangnya perhatian pemerintah terhadap kesejahteraan guru, masih ada guru-guru honorer yang dibayar dengan angka yang sangat rendah. Peneliti berharap dengan hadirnya MAN Insan Cendekia di Halmahera Barat ini bisa menjadi peluang besar untuk memajukan daerah Maluku Utara.

\section{Akreditasi Sebagai Ukuran Mutu Man Insan Cendekia Halmahera Barat.}

Akreditasi adalah kegiatan penilaian kelayakan program dalam satuan pendidikan berdasarkan kriteria yang telah ditetapkan. Akreditasi sekolah merupakan kegiatan penilaian yang dilakukan oleh pemerintah dan/atau lembaga mandiri yang berwenang untuk menentukan kelayakan program dan/atau satuan pendidikan pada jalur pendidikan formal dan nonformal pada setiap jenjang dan jenis pendidikan, berdasarkan kriteria yang telah ditetapkan, sebagai bentuk akuntabilitas publik yang dilakukan secara objektif, adil, transparan, dan komprehensif dengan menggunakan instrumen dan kriteria yang mengacu kepada Standar Nasional Pendidikan. Akreditasi adalah proses penilaian dengan indikator tertentu berbasis fakta. Asesor melakukan pengamatan dan penilaian sesuai realitas, tanpa ada manipulasi. Akreditasi dilakukan dengan tujuan untuk memperoleh gambaran keadaan kinerja madrasah dalam menyelenggarakan pendidikan, sebagai dasar yang dapat digunakan sebagai alat pembinaan dan pengembangan dalam rangka peningkatan mutu pendidikan di madrasah (Depag RI, 2008: 7). 
Tabel 2.

Nilai Akreditasi MAN Insan Cendekia Halbar 2018.

\begin{tabular}{|c|l|c|}
\hline No & \multicolumn{1}{|c|}{ Komponen } & Nilai \\
\hline 1 & Standar isi & 9 \\
\hline 2 & Strandar Proses & 9 \\
\hline 3 & Standar Kompetensi Lulusan & 9 \\
\hline 4 & Standar Pendidik dan Tenaga Kependidikan & 8 \\
\hline 5 & Standar Sarana dan Prasarana & 9 \\
\hline 6 & Standar Pengelolaan & 9 \\
\hline 7 & Standar Pembiayaan & 9 \\
\hline 8 & Stnadar Penilaian & 9 \\
\hline & Nilai Akhir & $\mathbf{9 2}$ \\
\hline
\end{tabular}

KLASIFIKASI PERINGKAT AKREDITASI

\begin{tabular}{|c|c|c|}
\hline Klasifikasi & Peringkat & Predikat \\
\hline $91 \leq$ Nilai Akhir $\leq 100$ & A & Unggul \\
\hline $81 \leq$ Nilai Akhir $\leq 90$ & B & Baik \\
\hline $71 \leq$ Nilai Akhir $\leq 80$ & C & Cukup Baik \\
\hline $0 \leq$ Nilai Akhir $\leq 70$ & TT & $\begin{array}{c}\text { Tidak } \\
\text { Terakreditasi }\end{array}$ \\
\hline
\end{tabular}

Dari gambar di atas membuktikan bahwa MAN Insan Cendekia memperoleh peringkat Akreditasi (A) dengan nilai (92) pada tahun 2018. Dengan jangka waktu yang singkat untuk memperoleh predikat tersebut sangatlah sulit, di tambah lagi madrasah ini mulai aktif pembelajaran pada Tahun 2017-201. Pemenuhan indikator dalam pencapaian delapan standar untuk menghasilkan peringkat terbaik. Apakah ini membuktukan penerapan manajemen mutu oleh kepala madrasah dalam mewujudkan madrasah bermutu di MAN Insan Cendekia. Tentu ada beberapa indikator yang menjadi tolak ukur untuk menentukan hasil tersebut. Dampak akreditasi madrasah terhadap peningkatan kinerja madrasah dari uraian di atas, dapat dilihat adanya hubungan antara akreditasi madrasah dengan penjaminan mutu pendidikan. Pada kenyataannya selain hubungan tersebut, akreditasi madrasah memberikan dampak atau akibat tidak langsung terhadap kinerja madrasa. Madrasah dengan akreditasi A tentu saja akan berusaha mempertahankan peringkat tersebut, semua komponen madrasah pasti tidak rela apabila peringkat madrasahnya turun menjadi B atau C. Untuk 
mempertahankan suatu prestasi memang lebih sulit dari pada meraih suatu prestasi. Diperlukan kesungguhan dan upaya terus menerus agar prestasi yang sudah diraih tidak hilang begitu saja.

Akreditasi sekolah membawa dampak positif kepada seluruh warga sekolah, antara lain:

a) Tumbuhnya kesadaran dari seluruh warga sekolah untuk memberikan dan meningkatkan pelayanan sesuai dengan standar atau kriteria yang ditetapkan dalam proses akreditasi.

b) Meningkatnya kerjasama seluruh komponen sekolah untuk memberikan yang terbaik untuk sekolah. Selain dampak positif, ada juga dampak negatif dari akreditasi sekolah terhadap kinerja sekolah, antara lain: Pertama, Peningkatan kinerja dari semua komponen sekolah hanya dilakukan menjelang pelaksanaan akreditasi sekolah, setelah selesai akan kembali seperti semula. Kedua, Ada sekolah yang melakukan rekayasa data untuk mencapai nilai akreditasi yang diharapkan (Aulia Ar Rakhman Awaludin, 2017).

\section{Implementasi Peningkatan kompetensi Guru MAN Insan Cendekia Halbar.}

Pada bagian ini peneliti akan memaparkan sejumlah data dan menganalisis yang berkaitan dengan implementasi peningkatan kompetensi guru di MAN Insan Cendekia Halmahera Barat, sejauh mana implementasi kepemimpinan kepala madrasah Insan Cendekia ini meningkatkan kinerja guru dan kompetensi siswa, untuk mewujudkan madrasah bermutu. Pengembangan sumber daya manusia dalam suatu organisasi merupakan hal yang penting. Investasi dalam pengembangan sumber daya manusia merupakan pengeluaran yang ditujukan untuk mem-perbaiki kapasitas produktif dari manusia. Aspek-aspek dalam pengembangan sumber daya manusia melingkupi beberapa hal yang cukup luas dalam organisasi.

Pengembangan sumber daya manusia, merupakan serangkaian aktivitas yang sistematis dan terencana yang dirancang oleh organisasi untuk memberikan kesempatan kepada anggotanya untuk mempelajari keahlian yang diperlukan untuk memenuhi persyaratan kerja saat ini dan yang akan datang. Kompetensi adalah kemampuan melaksanakan sesuatu yang diperoleh melalui pen didikan dan latihan Jadi kompetensi merupakan kemampuan yang memadai untuk melaksanakan suatu pekerjaan yang didapat melalui jalur pendidikan dan latihan. Kompetensi keguruan merupakan salah satu hal yang harus dimiliki serta dikuasai oleh para guru dalam jenjang pendidikan apapun (Indah Susilowati, Himawan Arif, Reni Daharti, 2013). 
Fajri Jufri mengungkapkan "Setiap kegiatan yang berkaitan dengan guru dan Siswa untuk meningkatkan kualitas sekolah, kami selalu di libatkan, saya sebagai guru Qur'an Hadist pernah mengikuti musyawarah guru mata pelajaran Qur'an Hadits se-Indonesia pada tahun 2018, itu menjadi pengalaman pertama saya ketika menjadi guru, dan saya sangat bersyukur mendapatkan ilmu dan pengalaman tersebut".

Sesuai dengan hasil wawancara di atas, dan di buktikan dengan gambar, bahwa kepala madrasah saat ini sangat konsentrasi dengan peningkatan kapasitas guru sebagai tenaga pendidikan yang professional, hal ini dapat membantu percepatan untuk mewujudkan mutu di MAN Insan Cendekia, tuntutan terhadap peningkatan kompetensi secara berkesinambungan disebabkan karena substansi kajian dan konteks pembelajaran selalu berkembang dan berubah menurut dimensi ruang dan waktu. Di samping itu, keharusan bagi setiap guru untuk mengembangkan kompetensinya secara terus-menerus dalam rangka pelaksanaan tugas dan tanggung jawab secara profesional, didorong juga oleh perkembangan dalam kehidupan bermasyarakat, perkembangan pemerintahan dan perubahan kurikulum pendidikan. Hal ini juga yang menjadikan setiap madrasah haruslah memberikan ruang kepada guru-guru untuk mengembangkan kompetensinya termaksud MAN Insan Cendekia Halmahera Barat. Kepala madrasah Insan Cendekia Halmahera Utara memberikan peluang kepada guru-guru untuk ikut serta dalam kegiatan-kegiatan pengembangan madrasah. Guru-guru dari MAN Insan Cendekia ini adalah guru-guru baru, yang direkrut dari berbagai Universitas di Maluku Utara, dengan kemampuan akademiknya masing-masing, sehingga dalam peningkatan kapasitas dan pengalaman sangat di butuhkan untuk menuju madrasah yang bermutu.

"Ini pertama kalinya saya memegang jabatan sebagai waka kurikulum sehingga menambah pengalaman bagi saya, sejauh yang saya ketahui bahwa kepala madrasah sangat menekankan pada pengembangan kapasitas guru, sehingga segiatan-kegiatan baik itu sosialisasi, workshop, ini selalu melibatkan guru-guru, ada juga inisiatif kepala sekolah misalnya pelatihan teknis untuk pembelajaran yang berbasis online itu kepala sekolah menghadirkan orang-orang yang kompoten untuk melakukan sosialisasi terkait dengan pembelajaran online tersebut, seperti penggunaan aplikasi oleh kementrian agama" (wawancara dengan Kartini K. Marsyaoly).

Dalam peningkatan kapasitas guru MAN Insan Cendekia Halmahera Barat, kepala madrasah selalu memberikan Perhatian penuh kepada guru dengan cara mengikutsertakan guru-guru dalam kegiatan worshop dan pelatihan-penalitahan untuk meningkatkan kualitas guru yang professional.

"Saya sudah beberapa kali mengikuti kegiatan-kegiatan untuk pengembangan guru, baik itu kegiatan berupa pelatihan computer kemudian sosialisasi manajemen 
asrama dari kementrian agama, ini sangat bermanfaat bagi kami guru-guru." (wawancara dengan M. Kamran).

Guru mempunyai tugas untuk mengarahkan kegiatan belajar siswa guna mencapai tujuan pembelajaran, oleh karena itu guru dituntut mampu menyampaikan bahan pelajaran dengan baik. Guru harus selalu memperbarui dan menguasai materi pembelajaran yang akan disampaikan. Di dalam pelaksanaan proses pembelajaran, guru harus memperhatikan prinsip-prinsip didaktik metodik sebagai ilmu keguruan. Dengan adanya sertifikasi diharapkan guru termotivasi untuk mengembangkan kemampuan dan kompetensi professional guru.

"Sejauh yang saya ketahui bahwa kepala madrasah Insan Cendekia ini sangatlah disiplin, beliau selalu menekankan guru dan siswa untuk mengembangkan kreaktifitas di madrasah, komunikasi dengan kamu guru-guru juga sangan baik. beliau tidak pernah marah. Kemudian teguran-teguran yang belia sampaikan dapat kami terima dengan baik, karena dengan pendekatan yang baik juga, meskipun kamu guru-guru mudah, beliau memperlakukan kami seperti teman guru" (wawancara dengan Kamran S Karim).

Dari hasil wawancara bahwa MAN Insan Cendekia terus berupaya meningkatkan kapasitas guru, perekrutan tenaga pendidik ini juga MAN Insan cendekia mengandalkan guru-guru muda yang berasal dari bererapa daerah di Maluku utara, untuk kepentingan masa depan MAN Insan Cendekia maka di lakukan lah seleksi guru berdasarkan ketentuan yang berlaku.

"Saya melihat untuk peningkatan kapasitas guru, terutama saya guru bahasa Arab di MAN Insan cendekia ini memiliki dua guru bahasa Arab kami belum di fasilitasi dengan lab Bahasa, karena masih dalam tahapan proses pembangunan, kemudian masih terdapat kekurang buku-buku bahasa arab dan buku pelajaran lainnya diperpustakaan.”

Pada dasarnya, faktor-faktor yang mempengaruhi keberhasilan pendidikan memang tidak hanya dari guru, karena di dalamnya termasuk siswa serta sarana dan prasarana serta kurikulum juga mempengaruhinya. Namun dari semua faktor itu, peran guru memang menjadi yang paling dominan dalam mewujudkan berkualitasnya pendidikan. Untuk mewujudkan pendidikan yang berkualitas memang membutuhkan sumber daya pendidik yang berkualitas pula. Guru merupakan komponen yang paling berpengaruh terhadap terciptanya proses dan hasil pendidikan yang berkualita Untuk mewujudkan pendidik yang berkualitas, selain dari tingkat pendidikan mereka sendiri juga dari faktor kesejahteraan. Kinerja guru yang baik akan menghasilkan peserta didik yang berkualitas dan cerdas. 
Sebagaimana yang di ketahui bahwa MAN Insan Cendekia Mendapat keistimewaan dari pemerintah, sehingga kemajuan madrasah ini sangat pesat.

\section{Prestasi Siswa MAN Insan Cendekia Halmahera Barat.}

Proses pendidikan merupakan aktivitas yang sangat panjang dan penuh dengan perencanaan yang matang dengan tujuan yang jelas seperti tertuang dalam UndangUndang Republik Indonesia Nomor 20 tahun 2003 tentang Sistem Pendidikan Nasional yaitu: Pendidikan Nasional berfungsi mengembangkan kemampuan dan membentuk watak serta peradaban bangsa yang bermartabat dalam rangka mencerdaskan kehidupan bangsa, bertujuan untuk berkembangnya potensi peserta didik agar menjadi manusia yang beriman dan bertaqwa kepada Tuhan Yang Maha Esa, berakhlak mulia, sehat, berilmu, cakap, kreatif, mandiri dan menjadi warga negara yang demokratis serta bertanggungjawab (Abd. Aziz Hsb, 2018).

Prestasi belajar merupakan hasil belajar seseorang yang diperoleh dari suatu proses pembelajaran dan hasil belajar yang diperolehnya merupakan hasil dari evaluasi atau penilaian yang dilakukan oleh guru kepada siswanya. Penilaiaan biasanya dalam bentuk nilai. Maka jelaslah bahwa prestasi yang diperoleh siswa merupakan upaya dalam pengembangan diri setelah mengikuti berbagai program latihan dan program pengajaran yang telah disusun dan direncanakan sedemikian rupa. Baik dalam bentuk kegiatan-kegiatan akademik dan non akademik. Semua itu demi terwujudkan prestasi yang gemilang dari para siswa, sehingga dapat meningkatkan mutu pendidikan madrasah. Pada bagian ini peneliti akan menggambarkan tingkat keberhasilan siswa MAN Insan Cendekia, hal ini dilakukan untuk mengukur seberapa besar implementasi visi kepala madrasah untuk mewujudkan mutu pendidikan di MAN Insan Cendekia.

Tabel 3.

Perstasi Akademik dan Non Akademik MAN Insan Cendekia Halbar.(2017-2020)

\begin{tabular}{|l|l|l|c|c|}
\hline No & PRESTASI & NAMA SISWA & TINGKAT & TAHUN \\
\hline 1 & $\begin{array}{l}\text { Juara Umum II Pekan Cinta } \\
\text { kreasi Gerakan Pramuka }\end{array}$ & $\begin{array}{l}\text { Gudep Habibi- } \\
\text { Ainun Manic Halbar }\end{array}$ & Provinsi & 2017 \\
\hline 2 & $\begin{array}{l}\text { Juara II Karya tulis Ilmiah } \\
\text { BKKBN Malut }\end{array}$ & Lisa Aprianti & Provinsi & 2018 \\
\hline 3 & $\begin{array}{l}\text { Juara III Fahmil Qur'an } \\
\text { Putra Rizaldi Izzul }\end{array}$ & Provinsi & 2018 \\
\hline 4 & $\begin{array}{l}\text { Juara I KSM Mapel } \\
\text { Ekonomi }\end{array}$ & Fathurahman & Kabupaten & 2018 \\
\hline
\end{tabular}




\begin{tabular}{|l|l|l|c|c|}
\hline 5 & $\begin{array}{l}\text { Finalis Olimpiade } \\
\text { Matematika Insight (HRO) }\end{array}$ & Faujan Attamimi & Nasional & 2019 \\
\hline 6 & $\begin{array}{l}\text { Juara 6 (10 besar) LOP ke-7 } \\
\text { Se-Indonesia Mapel } \\
\text { Ekonomi }\end{array}$ & King Abdul Aziz & Nasional & 2019 \\
\hline 7 & $\begin{array}{l}\text { Juara 9 (10 besar) LOP ke-7 } \\
\text { Se-Indonesia Mapel Sejarah }\end{array}$ & Nadilah Magfirah & Nasional & 2019 \\
\hline 8 & $\begin{array}{l}\text { Juara 9 Olimpiade pelajar } \\
\text { ke-8 se-Indonesia Mapel } \\
\text { Geografi }\end{array}$ & Salsabillah Pontoh & Nasional & 2019 \\
\hline 9 & $\begin{array}{l}\text { Semi Final Olimpiade } \\
\text { Biologi Nasional Ke-XI UIN } \\
\text { Malik Ibrahim Malang }\end{array}$ & Titah Prayudita & Nasional & 2020 \\
\hline
\end{tabular}

Dengan mengikutsertakan siswa dalam kegiatan-kegiatan yang berskala nasional ini di harapakan dapat memberikan kemajuan dalam pengelenggaraan pendidikan, sehingga kualitas peserta didik ini semakin di tingkatkan. perencanaan peningkatan kualitas peserta didik adalah suatu aktivitas memikirkan dimuka tentang hal-hal yang harus dilakukan berkenaan dengan peserta didik di lembaga pendidikan, baik sejak peserta didik akan memasuki lembaga pendidikan maupun mereka akan lulus dari lembaga pendidikan. Perencanaan yang dilakukan sejang penerimaan siswa baru sampai pada proses pembelajaran dan proses evaluasi sampai peserta didik keluar dengan mendapatkan prestasi yang cemerlang. Langkah-langkah perencanaan peserta didik dimulai dengan perkiraan, rumusan tujuan, penyusunan program, penjadwalan, dan pembiayaan (Muhammad Khoirul Umam, 2018: 63-64).

"Prestasi di MAN Insan Cendekia Halbar ini sangat banyak, arahnya di bidang sains dan keagamaan, bidang sains ini seperti olimpiade nasional, kompetensi sains madrasah, matetmatika, biologi, dan hampir semuanya mendapatkan juara dan untuk yang internasional baru satu siswa, di bidang matematika dan untuk kegiatan ke-Agamaan seperti kegiatan MTQ, STQ tingkat daerah itu ada siswa-siwa kami yang di ikutkan.” (Wawancara dengan Amiruddin La Dae, Waka Keasramaan).

Dari hasil wawancara diatas menungjukan bahwa kegiatan perlombaan baik tingkatan daerah maupun nasional yang di ikuti oleh siswa-siswi MAN Insan Cedekia Halmahera Barat, hal ini menunjukan suatu prestasi akademik dan non akademik dari siswa-siswi untuk meningkatkan mutu madrasah. Keberhasilan ini juga berkaitan dengan keadaan madrasah yang turut mempengaruhi tingkat keberhasilan siswa. Lingkungan madrasah juga menyangkut lingkungan akademis, yaitu sarana dan pelaksanaan kegiatan belajar mengajar, berbagai kegiatan ekstrakurikuler dan lain sebagainya. Lingkungan belajar sangat membantu siswa dalam menambah pengetahuan dan ilmu untuk peningkatan wawasan dan 
daya pikir siswa lingkungan belajar akan menjadi kondusif bila adanya kerjasama yang baik diantara komponen lingkungan belajar. Guru secara aktif merangsang dan mengamati keadaan atau kondisi dalam proses belajar mengajar dan dapat mengambil tindakan yang semestinya untuk membuat suasana dan keadaan belajar kondusif.

"kepala madrasah sering mengingatkan guru-guru, untuk selalu memperhatikan prestasi siswa, karena ini menyangkut nama baik madrasah, sejauh yang saya Ketahui bahwa, siswa kami di MAN Insan Cendekia ini sudah banyak mengikuti kegiatan-kegiatan daerah dan nasional dan hampir semua kejuaraan di daerah itu siswa-siswa kami yang mendapatkan juara." (Wawancara Via WhatsApp,Kartini K. Marsyaoly).

Setiap siswa-siswi MAN Insan Cendekia Halmahera Barat wajib tinggal di asrama. Asrama siswa saat ini dalam satu bangunan yang terdiri dari dua lantai, lantai satu di tempati oleh siswa putra dan lantai dua oleh siswa putri. Guru-guru yang membina dan mengawasi serta menjadi pengganti orang tua siswa dalam kehidupannya. Hal ini sebabkan karena asrama putri masih dalam tahapan pembangunan dan direncanakan akan dapat di tempati pada tahun 2021. Seluruh jadwal kegiatan harian dan pekanan, dilaksanakan melalui bimbingan dan kerjasama antar siswa dan pembina asrama yang tinggal bersama di MAN Insan Cendekia Halmahera Barat.

"Untuk penerimaan siswa baru, seluruh MAN Cendekia yang ada sudah memiliki sistem yang di tetapkan oleh Kementrian Agama, untuk tahun ini berapa banyak siswa, kapasitas ruangan berapa, guru yang harus di rekrut berapa, itu sudah di atur berdasarkan sistem online, karena madrasah ini mendapatkan perhatian khusus dari kementrian. Rata-rata siswa yang di terima adalah siswa yang berprestasi dari asal sekolah mereka (Wawancara, M. Zaimunir).

Program keasramaan hampir semua MAN Insan Cendekia sama yang menjadi perbedaaan disini kreaktifitas kepala sekolah dan guru untuk mengatur dan menambahkan apa yang menjadi program unggulan, sesuai dengan kebutuhan siswa di tempat masingmasing, program keasraamn meliputi: 1) pembinaan kehidupan sosial di asrama. 2) penggerakan siswa untuk salat berjamaah di masjid. 3) menjaga kebersihan asrama dan lingkungannya. 4) pengaturan kegiatan siswa sore hari. 5) kegiatan belajar mandiri malam hari. 6) pengecekan sarana siswa di asrama. 7) Razia barang-barang siswa yang di larang. 8) senam/olah raga bersama. 9) muhadhoroh/ muhadatsah. 10) merekap kegiatan harian siswa untuk dilaporkan kepada orang tua.

'Untuk pembelajaran keasramaan ini ada pembelajaran kitab, hafidzul Qur'an, hafidzul Hadits, yang di lakukan setiap hari di ba'dah magrib untuk hafidzul Qur'an, dan untuk pembelajaran Kitab di yang di laksanakan di setiap hari sabtu, karena adanya pandemi ini, jadi pengajian kitab ini kami lakukan secara online, ada beberapa kitab yang 
menjadi rujukan, yaitu kitab safinatun najah, aqidahtul awam, dan kitab talim mutaalim. Sedangkan untuk hadits yang menjadi rujukan itu hanyalah hadits arbain An-Nawawi."

(Wawancara Via WhatsApp, Amiruddin La Dae, Waka Keasramaan).

Penghafalan al-Qur'an sebagai “simbol” penanda MAN Insan Cendekia Halmahera Barat sebagai madrasah yang memadukan antara pengetahuan sains teknologi dan keAgamaan selama ini sudah di jalankan oleh madrasah. Perlu adanya pendataan kepada siswa penghafal Qur'an. Sehingga ada jumlah yang meningkat selama siswa mengikuti kegiatan hafalan di MAN Insan Cendekia sebab siswa-siswi penghafal Qur'an ini adalah mereka yang sudah menjadi penghafal Qur'an di madrasah awal sebelum masuk di MAN Insan Cendekia, ini yang menjadi catatan kritikan dari peneliti untuk pengelolaan pendidikan asrama nonakademik.

Tabel 4,

Data Hafidz Qur'an Siswa MAN Insan Cendekia Halbar

\begin{tabular}{|c|c|l|c|l|}
\hline NO & KATEGORI & NAMA SISWA/TTL & KELAS & MADRASAH ASAL \\
\hline 1 & $7 \mathrm{Juz}$ & $\begin{array}{l}\text { Fauzan Attamimi/25 mei } \\
2004\end{array}$ & XI & $\begin{array}{l}\text { SMP Alkhairaat } \\
\text { Ambon }\end{array}$ \\
\hline 2 & $5 \mathrm{Juz}$ & $\begin{array}{l}\text { Isti N. Amalia Ibrahim/Soa } \\
\text { sio 12 Juni 2002 }\end{array}$ & XII & $\begin{array}{l}\text { Ponpes IMIM } \\
\text { Makassar Sulawesi } \\
\text { Selatan }\end{array}$ \\
\hline 3 & $8 \mathrm{Juz}$ & $\begin{array}{l}\text { Kamila Citra } \\
\text { Humairah/Cemara Jaya, 24 } \\
\text { Maret 2014 }\end{array}$ & X & $\begin{array}{l}\text { MTS Ibadurrahman } \\
\text { Haltim }\end{array}$ \\
\hline 4 & $5 \mathrm{Juz}$ & $\begin{array}{l}\text { Rizaldi/Ba nyuwangi, 23 } \\
\text { Desember 2001 }\end{array}$ & XII & MTs N Haltim \\
\hline 5 & $5 \mathrm{Juz}$ & $\begin{array}{l}\text { Dimasqi Zukri Pinoke } \\
\text { /Towara,25 Maret 2002 }\end{array}$ & XII & MTs N 3 Halut \\
\hline
\end{tabular}

"Program pembinaan keasramaan ini kita lakukan melalui pola harian, pekanan, dan semester. Sesuai dengan bimbingan teknis dari kementrian agama. Pola pembinaan harian adalah kegiatan yang dilakukan setiap hari dan terjadwal secara nyata, yakni salat berjamaah lima waktu di masjid, wirid dan doa, kultum dan tausiah harian, tadarus Alquran setelah salat magrib dan salat subuh, pembacaan tausiah setelah salat zuhur dan magrib, pembiasaan menebarkan salam yakni mengucapkan salam ketika berjumpa dengan guru, dan siswa lainnya di mana pun dan kapan pun, dan pembiasaan menjadi imam salat fardu kepada siwa putra kelas tiga secara bergiliran." (Wawancara Via WhatsAPP, Fajri Jufri ).

Dapat di lihat dalam wawancara dan data diatas, MAN Insan Cendekia ini memiliki konsentrasi pengembangan pembelajaran di asrama, hal ini disesuaikan dengan bimbingan teknis dari Kementrian Agama. Selalu ada kontroling dalam kegiatan pembinaan yang sudah di rencanakan sehingga dapat berjalan sesuai dengan harapan. Hal ini membutuhkan kerja 
sama oleh semua elemen madrasah. Sebgaimana yang diketahui bahwa pengelolaan asrama ini sangat membutuhkan tenaga-tenaga yang profesional, dalam pengamatan peneliti, jumlah tenaga Pembina asrama masih di satukan dengan guru-guru, sehingga ada peran ganda, ini menujukan masih ada kekurang tenaga Pembina asram, sehingga pembinaan bisa terfikus pada siswa.

\section{KESIMPULAN}

Strategi kepemimpinan kepala madrasah dalam mewujudkan madrasah bermutu di MAN Insan Cendekia Halmahera Barat ini dijabarkan melalui indikotor-indikator yang berupa konsep, program, strategi pelaksanaan dan evaluasi mutu pendidikan. Programprogram dalam penguatan kompetensi guru sudah di laksanakan, melalui keterlibatan guru Insan Cendekia Halmahera Barat dalam berbagai kegiatan, diantaranya pengembangan kapasitas guru mata pelajaran, kegiatan worksshop, pelatihan komputer, serta bimbingan teknis keasramaan kemudian untuk tingkat keberhasilan siswa yang di buktikan dengan prestasi-prestasi dalam pengembangan pembelajaran sains teknologi dan keagamaan yaitu, kegitan olimpiade daerah maupun nasional, kegiatan ekstra pramuka, dan perlombaan seperti MTQ dan STQ. Pelaksann yang dilakukan dalam visi dan misi madrasah untuk mewujudkan mutu. Sehingga indikator-indikator dalam pelaksanaan mutu menujukan kepala madrasah memiliki strategi ampuh untuk memberikan mutu terbaik untuk kebutuhan pendidikan di madrasah Insan Cendekia Halmahera Barat.

\section{DAFTAR PUSTAKA}

Abd. Aziz Hsb. (2018). Kontribusi Lingkungan Belajar Dan Proses Pembelajaran Terhadap Prestasi Belajar Siswa di Sekolah. Jurnal Tarbiyah, 25(2).

Aulia Ar Rakhman Awaludin. (2017). Akreditasi Sekolah Sebagai Suatu Upaya Penjaminan Mutu Pendidikan Di Indonesia. Jurnal SAP, 2(1).

Depag RI. (2008). Pedoman Akreditasi Madrasah. Direktoral Jenderal Kelembagaan Agama Islam.

Fred David. (2009). Manajemen Strategi. Jakarta:Salemba Empat.

Finda Nestria Jelita dan Ary Ferdia. (2019). Pengaruh Sistem Manajemen Mutu ISO 9001:2015 Terhadap Kinerja Guru di Sekolah Menengah Atas. Jurnal Manajemen dan Pendidikan Islam, 5(1): 64

http://www.manichalbar.sch.id/profil.php?id=profil\&kode=12\&profil=Sejarah\%20Singka.

H.A. Rusdiana. (2015). Pengelolaan Pendidikan. Bandung: CV Pustaka Setia.

Indah Susilowati, Himawan Arif, Reni Daharti. (2013). Strategi Peningkatan Kompetensi Guru Dengan Pendekatan Analysis Hierarchy Process. 2. 
Kunandar, Guru Profesional: Implementasi Kurikulum Tingkat Satuan Pendidikan (KTSP) Dan Persiapan Menghadapi Sertifikasi (Jakarta: Raja Grafindo Persada, 2007),

Muhammad Fadhli. (2017). Manajemen Peningkatan Mutu Pendidikan. TADBIR: Jurnal Studi Manajemen Pendidikan, 1(02).

Mulyasa, E. (2005). Menjadi Guru Profesional Menciptakan Pembelajaran Kreatif dan Menyenangkan. Bandung: Remaja Rosda Karya.

Muhammad Khoirul Umam, Peningkatan Mutu Pendidikan Melalui Manajemen Peserta Didik, Jurnal Al-Hikmah 6, no. 2 (2018).

Mujamil Qomar. (2017). Manajemen Pendidikan Islam, Strategi Baru Pengelolaan Lembaga Pendidikan Islam. Jakarta: Penerbit Erlangga.

Muh Hadi, , Djailani AR, Sakdiah Ibrahim. (2014). Strategi Kepala Madrasah Dalam Meningkatkan Mutu Pendidikan Pada Min Buengcala Kecamatan Kuta Baro Kab Aceh Besar. Jurnal Administrasi Pendidikan, 4(2).

Sondang P, Siagian. (1989). Fungsi-fungsi Manajarial. Jakarta:Bina Aksara.

Suwadi. (2015). Vitalisasi Sekolah Berbasis Modal Sosial, Studi Kasus Penguatan Sekolah Melalui Integrasi Modal Sosial Dalam Kepemimpinan Sekolah di SMP Diponegoro Depok Sleman. Jurnal Pendidikan Agama Islam, XII(2).

Trisnawati. (2019). Manajemen Sarana Pendidikan Dalam Meningkatkan Mutu Pembelajaran Sd Negeri Lamteubee Aceh Besar. Jurnal, 7(1). 